\title{
ДИНАМІКА ЗМІН ПОКАЗНИКІВ ЦИТОКІНОВОГО ПРОФІЛЮ У ТВАРИН, УРАЖЕНИХ ВАЖКИМИ МЕТАЛАМИ І ФОСФОРОРГАНІЧНИМИ ПЕСТИЦИДАМИ
}

Вступ. Відомо, що вплив різних забруднювачів навколишнього середовища, таких, як важкі метали і оросфророрганічні сполуки, викликає різні зміни в організмі людини, які характеризуються вивільненням цитокінів, утворенням активних фрорм Оксигену, що пояснює виникнення різних імунологічних та запальних процесів. Іони важких металів можуть індукувати або пригнічувати синтез запальних та прозапальних цитокінів. На сьогодні комбінована дія важких металів і фросфророрганічних пестицидів на імунну систему залишається недостатньо вивченою.

Мета дослідження - вивчити вплив Плюмбуму ацетату, Купруму сульфрату і гліфосату в фрормі раундапу на стан імунної системи та вміст інтерлейкінів у щурів різного віку.

Методи дослідження. Досліди проводили на лабораторних нелінійних білих щурах-самцях трьох вікових груп: статевонезрілих, статевозрілих і старих, яким внутрішньошлунково протягом 30-ти днів вводили водні розчини Плюмбуму ацетату, Купруму сульфату і гліфросату (у фрормі гербіциду раундапу). Стан імунної системи оцінювали за рівнем імуноглобулінів класів A, G, M, циркулюючих імунних комплексів та цитокінів у сироватці крові тварин.

Результати й обговорення. Встановлено, що при введенні щурам водних розчинів Плюмбуму ацетату, Купруму сульфрату і гліфосату (у формі гербіциду раундапу) в комбінації й окремо порушилось співвідношення імуноглобулінів та інтерлейкінів, підвищилась концентрація циркулюючих імунних комплексів у сироватці крові уражених тварин. При введенні досліджуваних ксенобіотиків окремо та в комбінації у тварин усіх вікових груп пригнічувалась гуморальна ланка імунітету, про що свідчили підвищення концентрації циркулюючих імунних комплексів та зниження вмісту імуноглобулінів, особливо в молодих і старих щурів. Результати досліджень показали, що при дії токсикантів у сироватці крові тварин усіх вікових груп збільшувалась концентрація інтерлейкіну-1 $\beta$, інтерлейкіну-6, фрактора некрозу пухлини- $\alpha$ та зменшувався вміст інтерлейкіну-4, інтерлейкіну-10. Інтоксикація Купруму сульфратом, Плюмбуму ацетатом і фросфорорганічним пестицидом супроводжувалася порушенням балансу цитокінів з переважанням прозапальних, розвитком запальних процесів, що може викликати функціональні та структурні ушкодження клітинних мембран і накопичення токсичних метаболітів.

Висновок. Вплив Плюмбуму ацетату, Купруму сульфрату і раундапу на запальні процеси призводить до пригнічення імунної системи тварин.

КЛЮЧОВІ СЛОВА: імунітет; імуноглобуліни; інтерлейкіни; Плюмбуму ацетат; Купруму сульфат; гліфосат.

ВСТУП. На сьогодні, згідно з даними ВООЗ, за кількістю та токсичністю у навколишньому середовищі свинець посідає друге місце серед отрут, які впливають на здоров'я і стан організму людини $[1,2]$. Незважаючи на те, що бензин, який містить сполуки свинцю, давно перестали використовувати в багатьох країнах (наприклад, у 1976-1986 pp. - у СРСР і США, a у 2005 p. -y Європейському Союзі), Плюмбумовмісні сполуки все ще додають до авіаційного палива. Крім того, хоча продаж свинцевих фрарб було заборонено у США наприкінці 1970-х років, а у Європейському Союзі - в 1992 р., їх усе ще застосо๑є. Б. Дмухальська, 2020. вують при реставрації і збереженні історичних будівель та мистецтва $[3,4]$.

Для свинцю не існує найнижчої безпечної концентрації, його сполуки викликають захворювання різної етіології і на всіх рівнях організму. Імунна система - одна з найбільш чутливих мішеней для іонів Плюмбуму, хоча при екологічно низькій їх концентрації спочатку не відзначають явних порушень основних функкцій клітини, проте з часом спостерігають накопичення патологічних метаболітів, що негативно впливає на регуляцію процесів та функції імунних клітин [5].

Мідь - один із 26-ти найважливіших мікроелементів, що містяться в тканинах рослин, 
тварин і людини. Однак підвищений вміст цього елемента змінної валентності викликає ряд порушень в організмі, одним з яких $є$ утворення надмірної кількості активних фрорм Оксигену, що призводить до розвитку в організмі оксидантного стресу, запальних процесів, порушення фрізіологічних фрункцій, пригнічення імунітету [6].

Не менш токсичними є фосоророрганічні пестициди [7], тому метою цього дослідження було вивчити окрему і комбіновану дію цих ксенобіотиків.

МЕТОДИ ДОСЛІДЖЕННЯ. 3 метою вИвчення впливу важких металів у поєднанні з фроссророрганічними пестицидами на імунну систему використовували лабораторних нелінійних білих щурів-самців трьох вікових періодів: статевонезрілих (молодих масою 70-90 г і віком 1-3 місяці), статевозрілих (дорослих масою 170-210 г і віком 5-8 місяців), старих (масою 250-300 г і віком 20-24 місяці). Вік тварин визначали за схемою В. І. Махінько та В. Н. Нікітіна [8].

Інтоксикацію в щурів моделювали шляхом щоденного перорального введення їм упродовж 30-ти діб водних розчинів Плюмбуму ацетату $\left(\left(\mathrm{CH}_{3} \mathrm{COO}\right)_{2} \mathrm{~Pb}\right)$ удозі 11 мг/кг маси тіла $\left(1 / 20 \mathrm{LD}_{50}\right)$, Купруму сульфрату (CuSO 4 ) у дозі 13 мг/кг маси тіла $\left(1 / 20 L_{50}\right)$, гліфосату (у фрормі гербіциду раундапу) в дозі 250 мг/кг маси тіла (1/20 LD $\left.{ }_{50}\right)$. Токсиканти вводили у комбінації та окремо. Як контроль використовували інтактних тварин, яким вводили питну водопровідну дехлоровану воду.

Піддослідних тварин усіх вікових періодів було поділено на такі групи: 1-ша - інтактні (контрольні); 2-га - уражені водним розчином Плюмбуму ацетату; 3-тя - уражені водним розчином Купруму сульсрату; 4-та - уражені гліфросатом (у формі раундапу); 5-та - комбіноване ураження водними розчинами Плюмбуму ацетату, Купруму сульфрату і раундапу. На 31-шу добу після останнього введення ксенобіотиків щурів виводили з експерименту за умов тіопентал-натрієвого (внутрішньочеревне введення $1 \%$ розчину 3 розрахунку 50 мг/кг маси тварини) наркозу.

Під час проведення досліджень усі щури перебували у віварії Тернопільського національного медичного університету імені І. Я. Горбачевського МОЗ України на стандартному раціоні відповідно до санітарно-гігієнічних норм. Утримували щурів та виконували всі експерименти на них із дотриманням національних (Закон України № 3447-IV "Про захист тварин від жорстокого поводження", 2006) та міжнародних (Європейська конвенція про захист хребетних тварин, що використовуються для дослідних та інших наукових цілей, Страсбург, 1986) за- гальних правил і рекомендацій щодо гуманного поводження з лабораторними тваринами [9-11].

Гуморальну ланку імунітету оцінювали за рівнем імуноглобулінів (Ig) класів A, G, М у сироватці крові біохімічним методом [12] та за кількістю циркулюючих імунних комплексів (ЦІК) у сироватці крові [12].

Концентрацію цитокінів у сироватці крові,

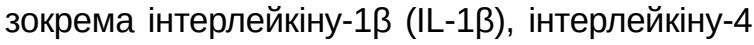
(IL-4), інтерлейкіну-6 (IL-6), інтерлейкіну-10 (IL-10) та фрактора некрозу пухлини- $\alpha$ (TNF- $\alpha$ ), визначали методом твердофразного імунофрерментного аналізу за допомогою набору реагентів "ELISA Kit for Rat Uscn, Life Science Inc" згідно з інструкціями фрірми-виробника.

Статистичну обробку цифрових даних здійснювали за допомогою програмного забезпечення Excel ("Microsoft", США) і Statistica 6.0 ("Statsoft", США) з використанням непараметричних методів оцінки одержаних даних. Для всіх показників розраховували значення середньої арифрметичної вибірки (М), її дисперсії і помилки середньої $(\mathrm{m})$. Достовірність різниці значень між незалежними кількісними величинами встановлювали за допомогою критерію Манна - Уїтні. Зміни вважали статистично достовірними при $\mathrm{p}<0,05$ [13].

РЕЗУЛЬТАТИ Й ОБГОВОРЕННЯ. ІМУНна система $є$ однією з найбільш чутливих мішеней за дії різних чинників. На вікові особливості її функціонування впливають як екзогенні, так і ендогенні фрактори [1]. Результати наших досліджень показали, що з віком в інтактних тварин підвищувалась концентрація циркулюючих імунних комплексів та імуноглобулінів (табл.). Так, вміст ЦІК у сироватці крові дорослих щурів зріс на $40 \%$, а в старих - на 65 \% порівняно 3 молодими тваринами. Таку ж тенденцію спостерігали при аналізі концентрації імуноглобулінів. Так, у дорослих щурів вміст IgА збільшився на $81 \%$, IgG - на $29 \%$, IgM - на $14 \%$ порівняно 3 молодими щурами. Концентрація IgA в сироватці крові старих тварин зросла у 2,9 раза, IgG - в 1,5 раза, IgM - в 1,3 раза від рівня молодих тварин. При введенні досліджуваних ксенобіотиків окремо та в комбінації у тварин усіх вікових груп пригнічувалась гуморальна ланка імунітету, про що свідчили підвищення концентрації ЦІК і зниження вмісту Ig, особливо в молодих і старих щурів. Це вказує на те, що у статевонезрілих тварин лабільна і ще недостатньо сорормована імунна система, а у старих щурів, за дії зовнішніх чинників, частково пригнічується імунна система, як і всі фрункції організму [5].

При аналізі комбінованого впливу солей важких металів і раундапу на щурів спостерігали 
Таблиця - Показники гуморального імунітету в сироватці крові щурів різного віку, уражених

Плюмбуму ацетатом, Купруму сульфатом, раундапом окремо та в комбінації (M $\pm m, n=10)$

\begin{tabular}{|c|c|c|c|c|c|c|}
\hline \multirow{3}{*}{ Вік } & \multirow{3}{*}{ Показник } & \multicolumn{5}{|c|}{ Група піддослідних тварин } \\
\hline & & \multirow{2}{*}{ інтактні } & \multicolumn{4}{|c|}{ уражені } \\
\hline & & & $\mathrm{CuSO}_{4}$ & $\left(\mathrm{CH}_{3} \mathrm{COO}\right)_{2} \mathrm{~Pb}$ & раундап & комбінована дія \\
\hline \multirow[t]{4}{*}{ Статевонезрілі } & ЦІК, ум. од./Л & $33,6 \pm 2,1$ & $42,3 \pm 2,4^{*}$ & $52,9 \pm 2,5^{\star}$ & $56,8 \pm 2,8^{*}$ & $65,8 \pm 2,4^{\star}$ \\
\hline & $\lg \mathrm{A}$, г/л & $1,13 \pm 0,04$ & $0,97 \pm 0,01^{*}$ & $0,84 \pm 0,02$ & $0,90 \pm 0,02^{*}$ & $0,70 \pm 0,01^{*}$ \\
\hline & $\operatorname{lgG}$, г/л & $4,19 \pm 0,09$ & $3,70 \pm 0,09$ & $3,00 \pm 0,04^{*}$ & $3,56 \pm 0,02^{*}$ & $2,85 \pm 0,03^{*}$ \\
\hline & $\operatorname{lgM}$, г/л & $8,58 \pm 0,08$ & $7,41 \pm 0,09$ & $7,05 \pm 0,10^{\star}$ & $7,01 \pm 0,01^{*}$ & $6,64 \pm 0,07^{*}$ \\
\hline \multirow[t]{4}{*}{ Статевозрілі } & ЦІК, ум. од./Л & $47,1 \pm 2,0$ & $51,3 \pm 1,7^{*}$ & $60,6 \pm 2,3^{*}$ & $61,2 \pm 2,3^{*}$ & $66,8 \pm 3,4^{*}$ \\
\hline & $\lg \mathrm{A}$, г/л & $2,04 \pm 0,03$ & $1,95 \pm 0,01^{*}$ & $1,90 \pm 0,02^{*}$ & $1,91 \pm 0,02^{*}$ & $1,84 \pm 0,02^{*}$ \\
\hline & $\operatorname{lgG}$, г/л & $5,41 \pm 0,08$ & $5,03 \pm 0,09$ & $4,74 \pm 0,04$ & $4,73 \pm 0,05$ & $4,28 \pm 0,05$ \\
\hline & $\lg \mathrm{M}$, г/л & $9,82 \pm 0,10$ & $9,04 \pm 0,08$ & $8,02 \pm 0,14^{\star}$ & $8,48 \pm 0,10$ & $7,94 \pm 0,12^{\star}$ \\
\hline \multirow[t]{4}{*}{ Старі } & ЦІК, ум. од./л & $55,7 \pm 2,0$ & $75,5 \pm 3,2^{\star}$ & $85,1 \pm 2,5^{\star}$ & $81,2 \pm 2,8$ & $93,3 \pm 2,8^{*}$ \\
\hline & $\lg \mathrm{A}$, г/л & $2,89 \pm 0,04$ & $2,24 \pm 0,03^{*}$ & $2,01 \pm 0,02$ & $2,30 \pm 0,02$ & $1,92 \pm 0,02^{*}$ \\
\hline & IgG, г/л & $6,08 \pm 0,02$ & $5,42 \pm 0,08$ & $4,81 \pm 0,08^{*}$ & $5,72 \pm 0,09$ & $4,27 \pm 0,07^{\star}$ \\
\hline & $\lg \mathrm{M}$, г/л & $10,67 \pm 0,11$ & $9,05 \pm 0,10$ & $7,74 \pm 0,10$ & $8,58 \pm 0,11$ & $7,21 \pm 0,10$ \\
\hline
\end{tabular}

Примітка. * - результати достовірні відносно інтактних тварин $(p<0,05)$.

зменшення вмісту Ig і збільшення концентрації ЦІК у сироватці крові тварин усіх вікових груп. Так, при ураженні раундапом, Купруму сульфатом і Плюмбуму ацетатом концентрація IgA в сироватці крові молодих щурів знизилася на 38 \%, у дорослих - на $10 \%$, а у старих - на $34 \%$ від рівня інтактних тварин (табл.). Подібно змінювався вміст IgG та IgM, найменшим він був у старих щурів, що становило, відповідно, 70 і 68 \% від рівня контролю. При комбінованій дії досліджуваних ксенобіотиків концентрація ЦІК зросла у всіх тварин, найвищою вона була у статевонезрілих щурів - 196 \%, у статевозрілих становила $142 \%$, у старих - 168 \% від рівня інтактних тварин (табл.).

Цитокіни - це біоактивні протеїни, що продукуються багатьма клітинами імунної системи та є ключовими медіаторами запальної реакції на вплив і взаємодію токсичних речовин із клітинами. Запальні реакції контролюють прозапальні (IL-1 $\beta$, IL-6, TNF- $\alpha$ та iн.) і протизапальні (IL-4, IL-10) цитокіни [14, 15].

Результати досліджень (рис. 1-3) показали, що при токсичному впливі важких металів і раундапу в сироватці крові щурів усіх вікових груп зростає концентрація IL-1ß, IL-6, TNF- $\alpha$ та знижується вміст IL-4, IL-10.

При введенні Купруму сульфрату і раундапу концентрація IL-1ß та IL-6 мало змінилась - підвищилась на 10-15 \% у сироватці крові тварин усіх вікових груп. За умов ураження водним розчином Плюмбуму ацетату концентрація IL-1 $\beta$ зросла в сироватці крові молодих щурів у 2,7 раза, дорослих - в 1,6 раза, старих -у 2,4 раза від

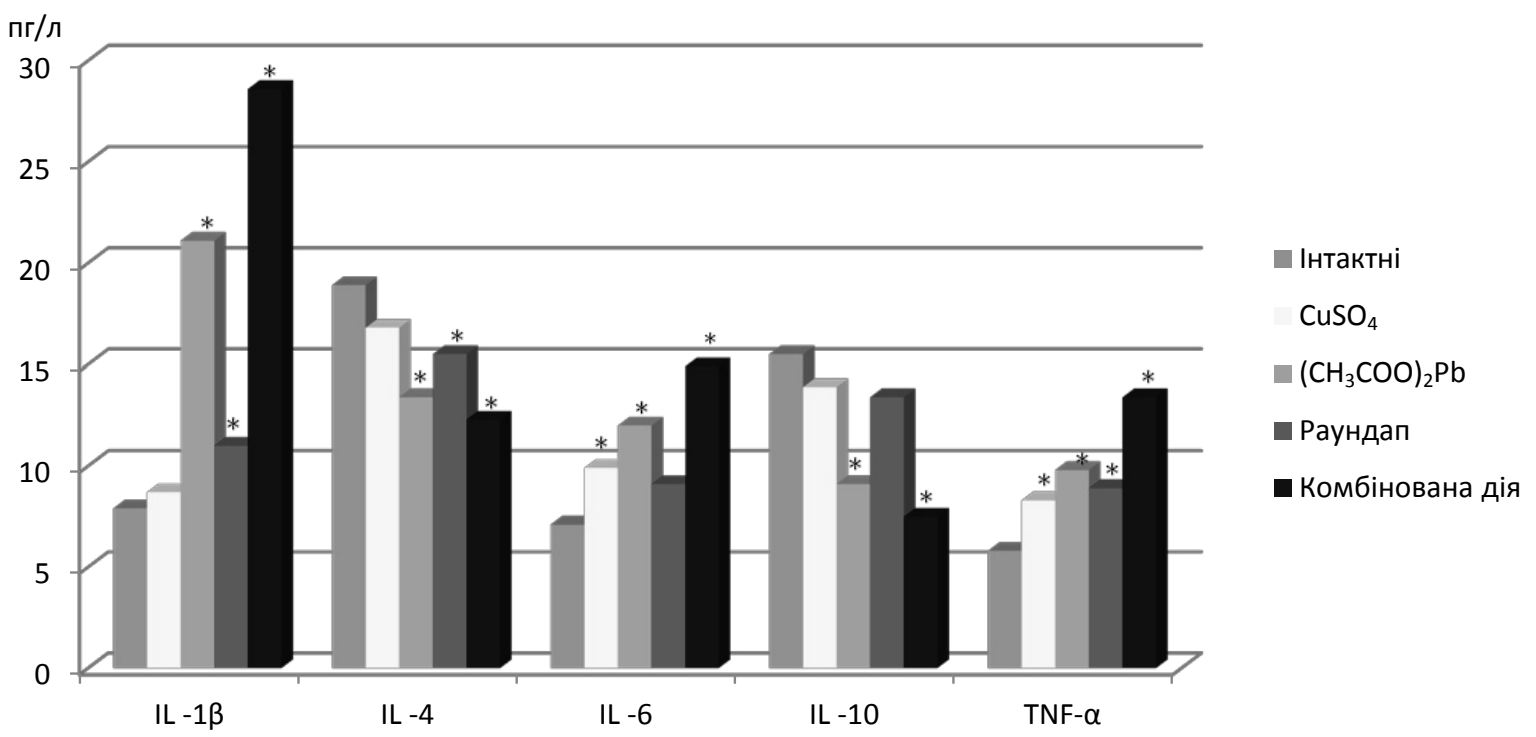

Рис. 1. Зміни вмісту прозапальних і протизапальних цитокінів у сироватці крові статевонезрілих щурів, уражених Плюмбуму ацетатом, Купруму сульфатом, раундапом окремо та в комбінації.

Примітка. Тут і на рисунках 2, 3: * - результати достовірні відносно інтактних тварин $(p<0,05)$. 


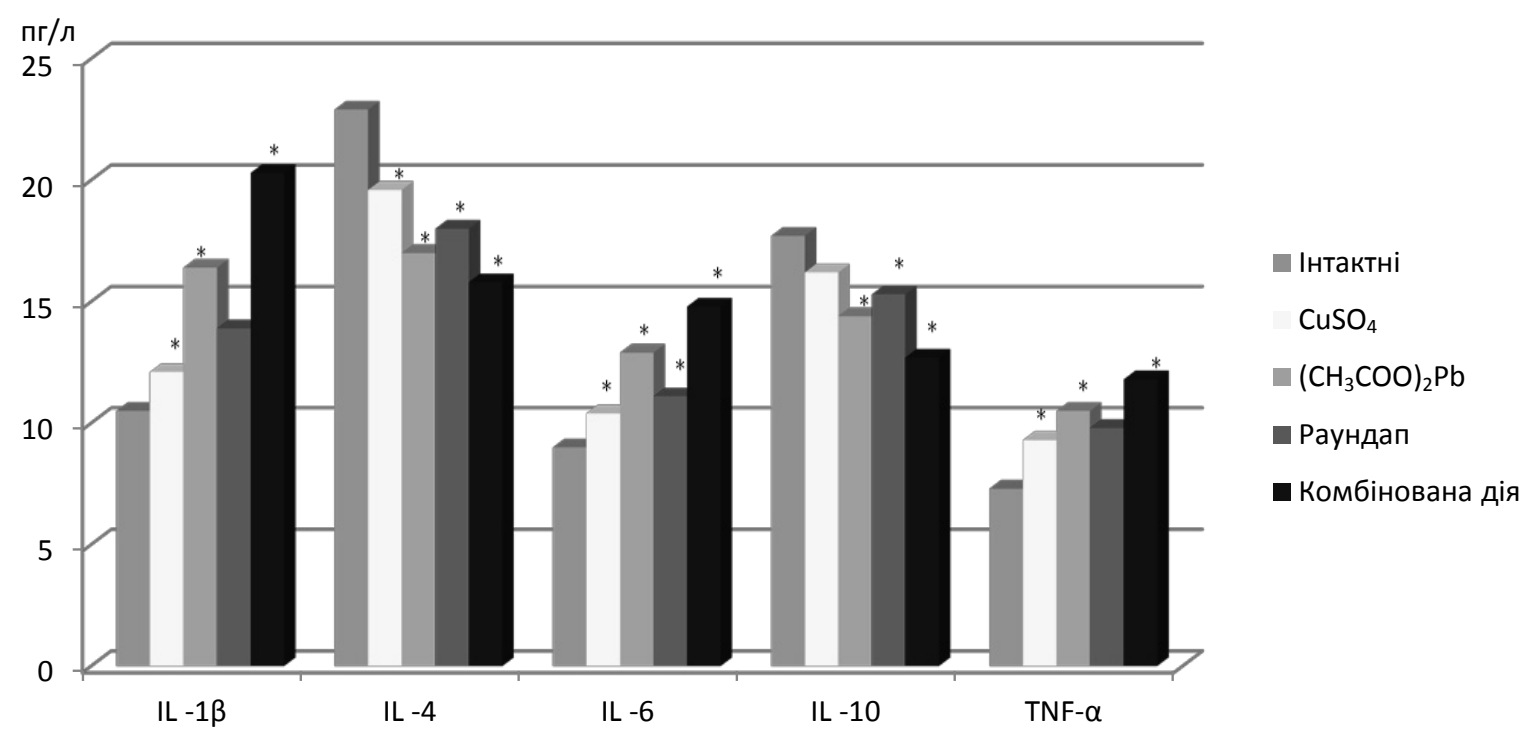

Рис. 2. Зміни вмісту прозапальних і протизапальних цитокінів у сироватці крові статевозрілих щурів, уражених Плюмбуму ацетатом, Купруму сульфратом, раундапом окремо та в комбінації.

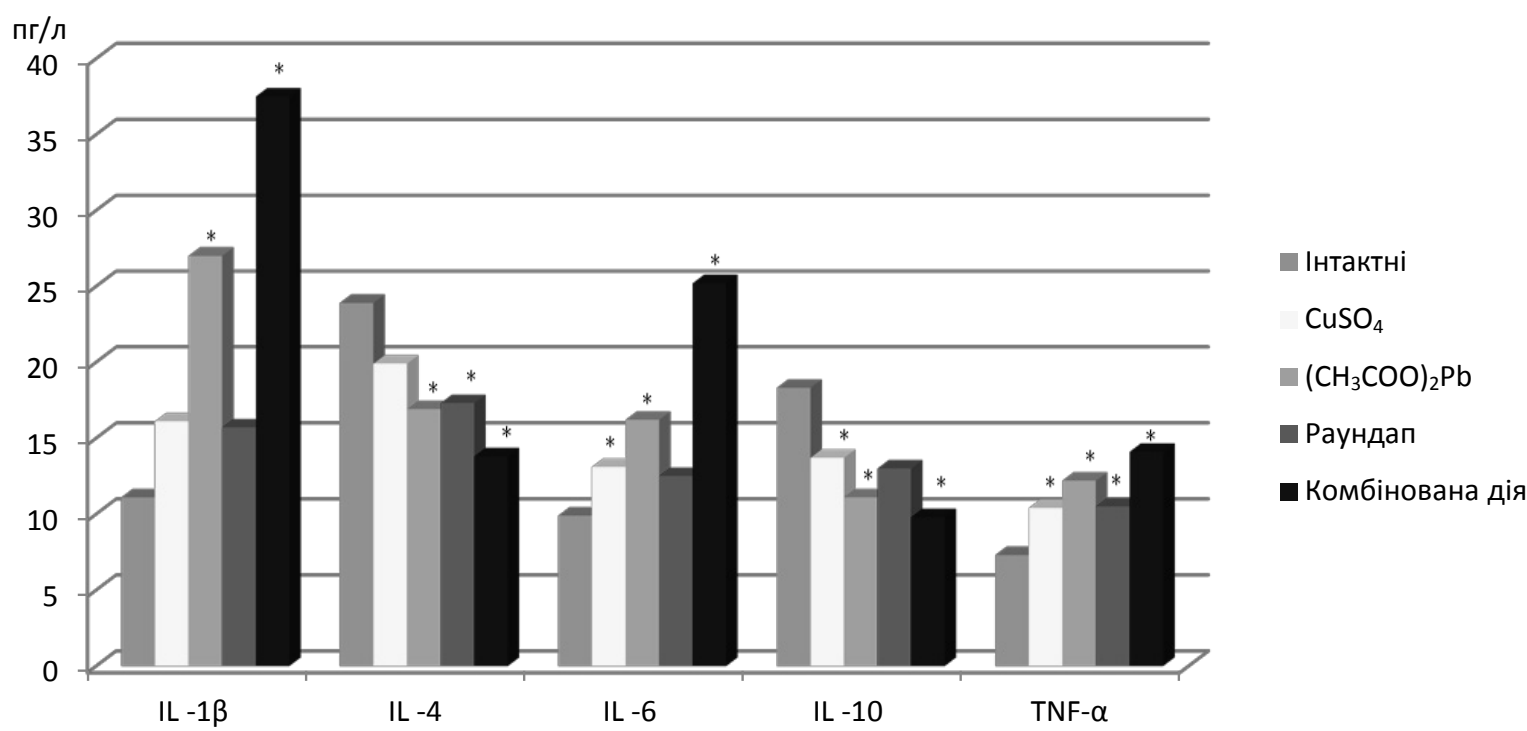

Рис. 3. Зміни вмісту прозапальних і протизапальних цитокінів у сироватці крові старих щурів, уражених Плюмбуму ацетатом, Купруму сульфатом, раундапом окремо та в комбінації.

рівня інтактних тварин. При комбінованій дії Плюмбуму ацетату, Купруму сульфату, раундапу вміст IL-6 у сироватці крові молодих щурів збільшився в 3,6 раза, дорослих - в 1,9 раза, старих у 3,4 раза від рівня контролю (рис. 1-3).

Як свідчать отримані результати (рис. 1-3), за умов комбінованого ураження вміст TNF- $\alpha$ у сироватці крові молодих щурів зріс у 2,1 раза, дорослих - в 1,6 раза, старих - в 1,9 раза відносно контрольної групи тварин.

Під час досліджень також встановлено, що поряд із зростанням вмісту прозапальних цитокінів знижувалась концентрація протизапальних цитокінів IL-4 та IL-10. Так, при одночасному введенні всіх токсикантів вміст IL-4 зменшився в молодих тварин на 34,9\%, у дорослих - на 31,0 \%, у старих - на 42,3 \% від рівня контролю.
Подібно змінився вміст цитокіну IL-10: знизився в сироватці крові молодих тварин на 51,6 \%, дорослих - на 28,3 \%, старих - на 46,5 \%.

При дії важких металів і фросфророрганічного пестициду порушується баланс цитокінів 3 переважанням прозапальних, розвиваються запальні процеси, що може зумовлювати функціональні та структурні ушкодження клітинних мембран і накопичення токсичних метаболітів.

Отже, підсумовуючи результати проведених досліджень, можна стверджувати, що використані токсиканти окремо і в комбінації по-різному впливають на різні ланки імунної системи тварин усіх вікових груп.

ВИСНОВКИ. 1. Введення водних розчинів Плюмбуму ацетату, Купруму сульорату, раундапу 
окремо і в комбінації супроводжується зниженням вмісту імуноглобулінів та інтерлейкінів у сироватці крові уражених тварин, що свідчить про пригнічення імунної системи.

2. Інтоксикація щурів важкими металами i раундапом призводить до порушення співвідношення вмісту запальних та прозапальних цитокінів.

\section{СПИСОК ЛІТЕРАТУРИ}

1. Цыганков В. Г. Изменение синтеза РНК под влиянием ионов свинца в иммунокомпетентных клетках / В. Г. Цыганков, Т. В. Латушко, Е. В. Барковский // Здоровье и окружающая середа : сб. науч. тр. - Мн., 2001. - C. 393-397.

2. ATSDR (Agency for Toxic Substances and Disease Registry's). CERCLA Priority Listof Most Hazardous Substances. - 2007. - Access mode : http://www.atsdr. cdc.gov/cercla.

3. The Restriction of the Use of Certain Hazardous Substancesin Electricaland Electronic Equipment Regulations; No. 2748. - 2005. - Access mode : http://www. legislation.gov.uk/uksi/2005/2748/pdfs/uksi_20052748_ en.pdf.

4. The Restriction of the Use of Certain Hazardous Substancesin Electrical and Electronic Equipment (Amendment) Regulations; No. 581. - 2009. - Access mode : http://www.legislation.gov.uk/uksi/2009/581/pdfs/ uksi_20090581_en.pdf.

5. Dietert R. R. Lead and immune function / R. R. Dietert, M. S. Piepenbrink // Crit. Rev. Toxicol. -2006. -36. P. 359-385.

6. Hedayati A. Serum hormone and biochemical activity asbiomarkers of mercury toxicity in the yellowfin seabream Acanthopagruslatus / A. Hedayati, A. Safahieh // Toxicol. Ind. Health. - 2012. - 28. - P. 306-319. DOI: $10.1177 / 0748233711410916$

7. Cotton Simon. Soundbite molecules / CottonSimon // EducationinChemistry. - 2005. - 42, No. 2. - P. 34. Access mode : http://www.rsc.org/Education/EiC/issues).
3. Встановлено вікову залежність підвищення вмісту циркулюючих імунних комплексів у сироватці крові інтактних та уражених ксенобіотиками щурів.

Перспективи подальших досліджень. Заплановано вивчити коригувальну дію низькомолекулярних пептидів на показники імунної системи щурів, уражених Купруму сульсратом, Плюмбуму ацетатом і раундапом.

8. Махинько В. И. Константы роста и фрункциональные периоды развития в постнатальной жизни белых крыс / В. И. Махинько, В. Н. Никитин // Молекулярные и фризиологические механизмы возрастного развития. - К. : Наукова думка, 1975.

9. Про захист тварин від жорстокого поводження : Закон України від 21.02.2006 р. № 3447-IV.

10. Науково-практичні рекомендації з утримання лабораторних тварин та роботи з ними / Ю. М. Кожем'якін, О. С. Хромов, М. А. Філоненко, Г. А. Сайсретдінова. - К. : Авіцена, 2002. - 156 с.

11. European convention for the protection of vertebrate animals used for experimental and other scientific purposes. - Council of Europe. Strasbourg, 1986. No. 123. -52 p.

12. Кишкун А. А. Иммунологические исследования и методы диагностики инсеекционных заболеваний в клинической практике / А. А. Кишкун. - М. : МИА, 2009. - 712 c.

13. Bernard Rosner. Fundamentals of Biostatistics. Boston, USA. - 2010. - 859 p.

14. Scheller J. The pro and anti-inflammatory properties of the cytokine interleukin $6 / \mathrm{J}$. Scheller, A. Chalaris, D. Schmidt Arras, et al. // Biochimica et Biophysica Acta (BBA). Molecular. Cell Research. - 2011. - 1831, № 5. P. 878-888.

15. Endothelial MMP-9 drives the inflammatory response in abdominal aortic aneurysm (AAA) / M. Ramella, F. Boccafoschi, K. Bellofatto [et al.] //Am. J. Transl. Res. 2017. - 9. - P. 5485-5495.

\section{REFERENCES}

1. Tsygankov, V.G., Latushko, T.V., \& Barkovskiy, E.V. (2001). Izmenenie sinteza RNK pod vliyaniem ionov svintsa $v$ immunokompetentnykh kletkakh [The influence of lead ions on the change of synthesis RNA in immunocompetent cells]. Zdorovye i okruzh. sreda: sb. nauch. tr. - Health and Environment: A Collection of Scien. Works. Minsk [in Russian].

2. (2007). ATSDR (Agency for Toxic Substances and Disease Registry's). CERCLA Priority List of Most Hazardous Substances. Retrieved from: http://www.atsdr. cdc.gov/cercla.
3. (2005). The Restriction of the Use of Certain Hazardous Substances in Electrical and Electronic Equipment Regulations; No. 2748. Retrieved from: http://www. legislation.gov.uk/uksi/2005/2748/pdfs/uksi_20052748_ en.pdf.

4. (2009). The Restriction of the Use of Certain Hazardous Substances in Electrical and Electronic Equipment (Amendment) Regulations; No. 581. Retrieved from: http://www.legislation.gov.uk/uksi/2009/581/pdfs/ uksi_20090581_en.pdf. 
5. Dietert, R.R., \& Piepenbrink, M.S. (2006) Lead and immune function. Crit. Rev. Toxicol., 36, 359-385.

6. Hedayati, A., \& Safahieh, A. (2012) Serum hormone and biochemical activity as biomarkers of mercury toxicity in the yellowfin seabream Acanthopagruslatus. Toxicol. Ind. Health, 28, 306-319. DOI: 10.1177/ 0748233711410916.

7. Cotton Simon. (2005) Soundbite molecules. Education in Chemistry, 42 (2), 34. Retrieved from: http:// www.rsc.org/Education/EiC/issues.

8. Makhinko, V. I., \& Nikitin, V. N. (1975). Konstanty rosta i funktsionalnyie periody razvitiya $v$ postnatalnoy zhizni belykh krys [Growth constants and functional development periods in the postnatal life of white rats]. Molekulyarnye i fiziologicheskie mekhanizmy vozrastnogo razvitiia -Molecular and physiological mechanisms of age development. Kyiv [in Russian].

9. Zakon Ukrainy "Pro zakhyst tvaryn vid zhorstokoho povodzhennia" vid 21.02.2006 r., No 3447 [The Law of Ukraine "On the Protection of animals from ill-treatment" of 02.21. 006, No. 3447]. [in Ukrainian].

10. Kozhemiakin, Yu.M., Khromova, O.S., \& Filonenko, M.A. (2002). Naukovo-praktychni rekomendatsii z utrymannia laboratornykh tvaryn ta robota z nymy [Scientific and practical recommendations for the maintenance of laboratory animals and work with them]. Kyiv: Avitsena [in Ukrainian].

11. (1986). European convention for the protection of vertebrate animals used for experimental and other scientific purposes Council of Europe. Strasbourg.

12. Kishkun, A.A. (2009). Immunologicheskie issledovaniya i metody diagnostiki infektsionnykh zabolevaniy $v$ klinicheskoy praktike [Immunological studies and methods for the diagnosis of infectious diseases in clinical practice]. Moscow: MIA [in Russian].

13. Bernard Rosner. (2010). Fundamentals of Biostatistics. Boston, USA.

14. Scheller, J, Chalaris, A, \& Schmidt Arras, D. (2011). The pro- and antiinflammatory properties of the cytokine interleukin 6. Biochimica et Biophysica Acta (BBA). Molecular. Cell Research, 1831 (5), 878-888.

15. Ramella, M., Boccafoschi, F., Bellofatto, K., Md, A.F., Fusaro, L., Boldorini, R.,Casella, F., Porta, C., Settembrini, P., \& Cannas, M. (2017) Endothelial MMP-9 drives the inflammatory response in abdominal aortic aneurysm (AAA). Am. J. Transl. Res., 9, 5485-5495.

\section{ДИНАМИКА ИЗМЕНЕНИЙ ПОКАЗАТЕЛЕЙ ЦИТОКИНОВОГО ПРОФИЛЯ У ЖИВОТНЫХ, ПОРАЖЕННЫХ ТЯЖЕЛЫМИ МЕТАЛЛАМИ И ФОСФОРОРГАНИЧЕСКИМИ ПЕСТИЦИДАМИ}

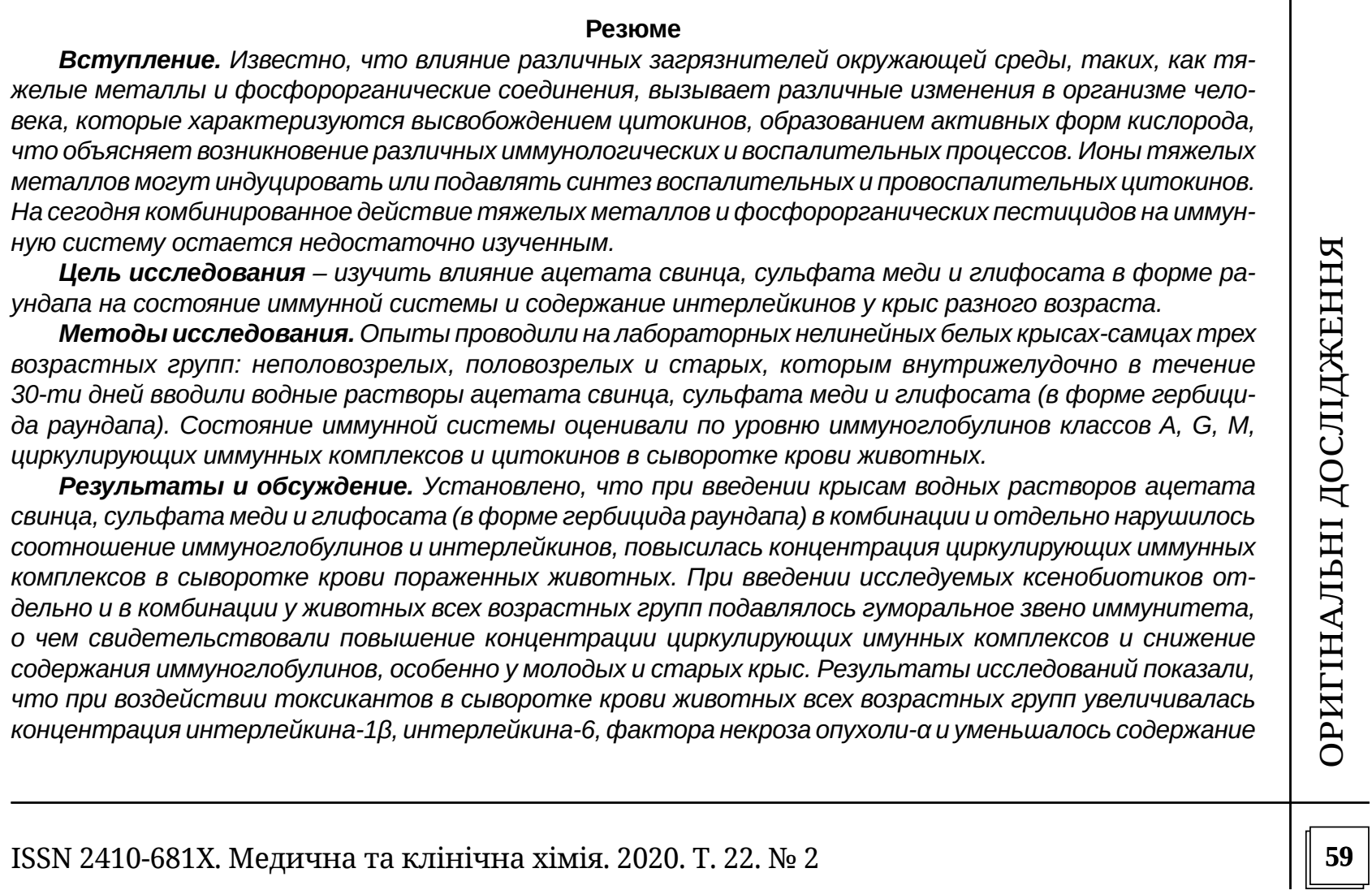


интерлейкина-4, интерлейкина-10. Интоксикация сульфратом меди, ацетатом свинца и фросфророрганическим пестицидом сопровождалась нарушением баланса цитокинов с преобладанием провоспалительных, развитием воспалительных процессов, что может вызывать фрункциональные и структурные повреждения клеточных мембран и накопление токсичных метаболитов.

Вывод. Влияние ацетата свинца, сульфата меди и раундапа на воспалительные процессы приводит к подавлению иммунной системы животных.

КЛЮЧЕВЫЕ СЛОВА: иммунитет; иммуноглобулины; интерлейкины; ацетат свинца; сульфат меди; глифосат.

Ye. B. Dmukhalska

I. HORBACHEVSKY TERNOPIL NATIONAL MEDICAL UNIVERSITY

\title{
CYTOKINE PROFILE CHANGES DYNAMIC IN ANIMALS AFFLICTED BY HEAVY METAL AND PHOSPHOORGANIC PESTICIDES
}

\begin{abstract}
Summary
Introduction. Exposure to various environmental pollutants, such as heavy metals and phospororganic compounds is known to induce different changes in human body, characterized by a release of cytokines, formation of reactive oxygen species, and to explain various immunological and inflammation processes. They can induce, or inhibit the synthesis of the inflammatory and proinflammatory cytokines. At present, the combined effect of heavy metals and phosphoorganic pesticides on the immune system remain insufficiently studied.
\end{abstract}

Research Methods. The experiment was carried out on lab nonlinear white rats - males three age periods: puberty, mature and old aging animals. The rats receiving the lead acetate, copper sulfate, glyphosate (in herbicide Roundup) in combined and peptide as correction agent. Subhronic lesions in rats was modelled by intragastric administration of water solution of Lead Acetate at a dose of $11 \mathrm{mg} / \mathrm{kg}$, Copper Sulfate at a dose of $13 \mathrm{mg} / \mathrm{kg}$, Glyphosate at a dose of $250 \mathrm{mg} / \mathrm{kg}$. Dehlorinated drinking tap water to intact animals was added. The immune system state was assessed by the level of immunoglobulin's IgA, IgG, IgM, circulating immune complexes and cytokines on the blood serum rats.

Results and Discussion. It was found that change of the immunoglobulins and interleukins ratio and the content of circulating immune complexes increases in the blood serum by the combined effect of lead acetate, copper sulfate and glyphosate (in Roundup form herbicide) water solutions in animals. The effect of these xenobiotics alone and in combination administration was analyzed. It was established that the content of circulating immune complexes was increased and concentration of immunoglobulins was decreased and the humoral part of the immune system was suppressed in blood serum of different age rats with glyphosate (in Roundup form herbicide), lead acetate, copper sulfate. Results of the present study showed that the concentration of IL-1 $\beta$, IL-6, TNF- $\alpha$ increased and the content of $I L-4, I L-10$ reduced in the blood serum of rats of all age groups. The balance of cytokines was a violation with a predominance of pro-inflammatory, involved in the inflammatory process, which can cause functional and structural damage to cell membranes and the accumulation of toxic metabolites in rats with toxicose by the action of copper sulfate, lead acetate and organophosphorus pesticide.

Conclusion. The influence of lead acetate, copper sulfate and roundup on inflammatory processes is multidirectional and led to the suppression of the immune system of animals.

KEY WORDS: immunity; immunoglobulins; interleukins; glyphosate; Lead acetate; Copper sulfate.

Адреса для листування: Є. Б. Дмухальська, Тернопільський національний медичний університет імені І. Я. Горбачевського моз України, майдан Волі, 1, Тернопіль, 46001, Україна, e-mail: dmukhalska@tdmu.edu.ua. 